\title{
WestVirginiaUniversity
}

THE RESEARCH REPOSITORY @ WVU

West Virginia Agricultural and Forestry Experiment

Davis College of Agriculture, Natural Resources

Station Bulletins

And Design

$1-1-1925$

\section{Feeding Experiments with Grade Beef Cows Raising Calves}

E. W. Sheets

R. H. Tuckwiller

Follow this and additional works at: https://researchrepository.wvu.edu/ wv_agricultural_and_forestry_experiment_station_bulletins

\section{Digital Commons Citation}

Sheets, E. W. and Tuckwiller, R. H., "Feeding Experiments with Grade Beef Cows Raising Calves" (1925). West Virginia Agricultural and Forestry Experiment Station Bulletins. 190.

https://researchrepository.wvu.edu/wv_agricultural_and_forestry_experiment_station_bulletins/190

This Bulletin is brought to you for free and open access by the Davis College of Agriculture, Natural Resources And Design at The Research Repository @ WVU. It has been accepted for inclusion in West Virginia Agricultural and Forestry Experiment Station Bulletins by an authorized administrator of

The Research Repository@WVU. For more information, please contact ian.harmon@mail.wvu.edu. 


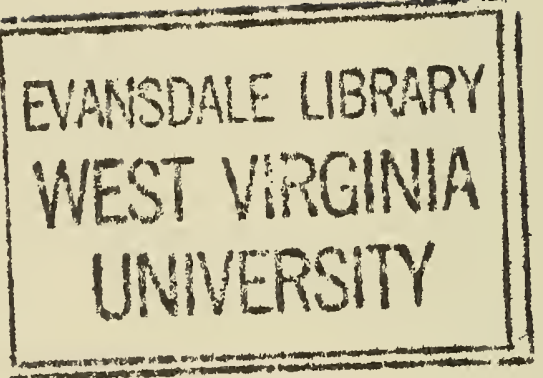


Restricted

\section{Circulation Only}

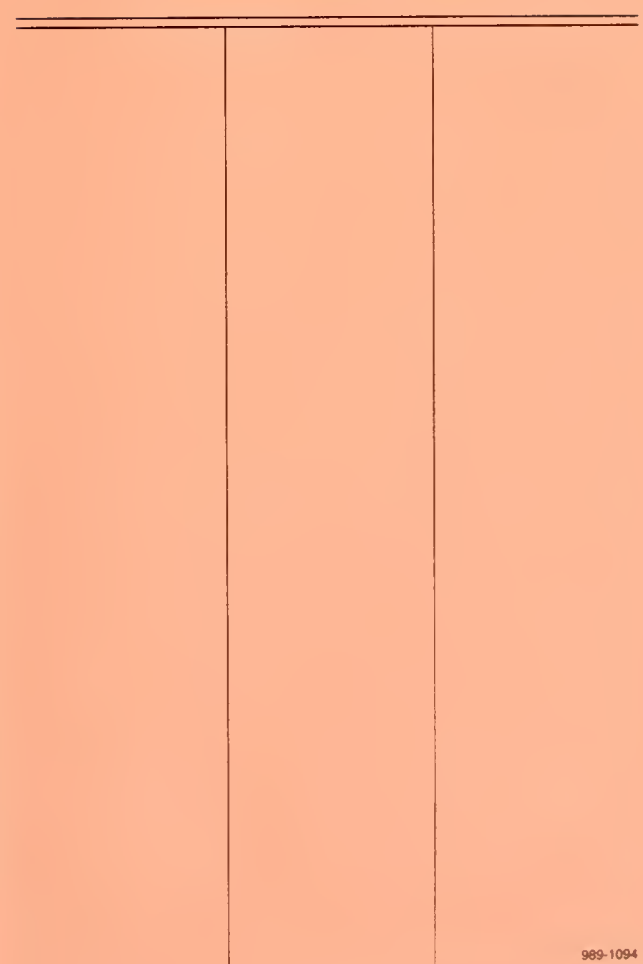




\section{Agricultural Fxumeriment \$atamn}

Collrụ of Auriculture, Hyst Hiruninia Huniurtsitu

HENRY G. KNIGHT, Director

Morgantown

\section{FEEDING EXPERIMENTS WITH GRADE BEEF COWS RAISING CALVES}

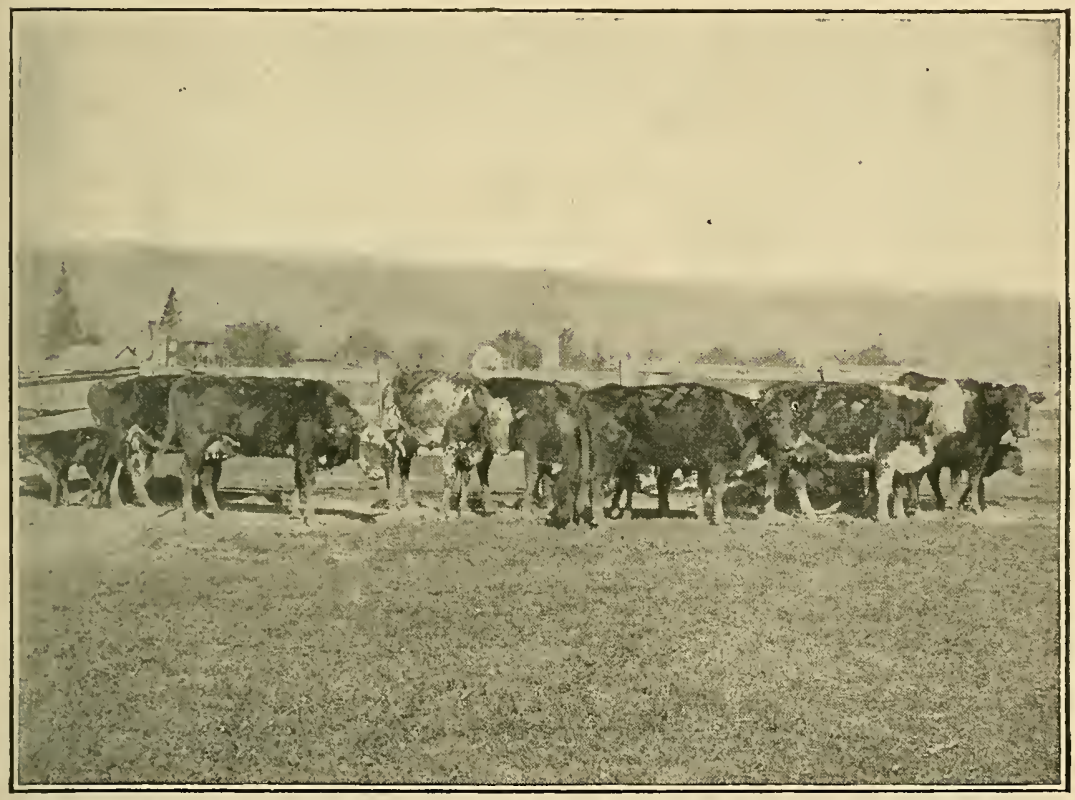

Fig. 4.-Lot 2. Cows Fed Corn Silage, Soy Bean Hay, and Wheat Straw, at the End of the Winter Period, April 25, 1919.

\section{BY}

E. W. SHEETS and

R. H. TUCKWILLER 


\section{AGRICULTURAL EXPERIMENT STATION STAFF}

FRANK B. TROTTER, A. M., LL. D. GEORGE R. LYMAN, Ph. D. HENRY G. KNIGHT, Ph. D. C. E. STOCKDALE, B. S. Agr. JOHN C. JOHNSTON
President of the Universit: Dean of the College of Agricultur Director of the Experiment Statior Agricultural Edito? Chief Clerl

\section{AGRONOMY}

R. J. Garber, Ph. D.

T. E. Odland, M. S.

Associate Agronomist

T. C. McIlvaine, Ph. D.

Assistant Agronomist

K. S. Quisenberry, B. S.*** Junior Agronomist

\section{ANIMAL HUSBANDRY}

E. A. Livesay, M. S.***

Animal Husbandman

Chas. V. Wilson, M. S.

Assistant Animal Husbandman

E. C. Stillwell, M. S.

Assistant Animal Husbandman

S. S. Wheeler, M. S.

Junior Animal Husbandman

R. H. Tuckwiller, B. S. Agr.*

Assistant Animal Husbandman

\section{CHEMISTRY}

Henry G. Knight, Ph. D. Chemist Chas. E. Weakley, Jr., B. A.,

T. B. Leith, B. A.**

Assistant Chemist

T. J. Cochran, B. S.

Assistant Chemist Junior Chemist

\section{DAIRY HUSBANDRY}

Ernest L. Anthony, M. S. Agr. Dairy Husbandman

H. O. Henderson, M. S. Agr.*** Associate Dairy Husbandman Warren Gifford,-B. S. Agr. Junior Dairy Husbandman G. M. Trout, M. S.

Assistant in Dairy Husbandry

\section{ENTOMOLOGY}

L. M. Peairs, M. S. Entomologist W. E. Rumsey, B. S. **

Assistant Entomologist

\section{FARM ECONOMICS}

A. J. Dadisman, Ph. D.

Paúl A. Eke, Ph. D.

Farm Economist

Junior Farm Economist

F. D. Cornell, M. S.

Junior Farm Mechanician W. W. Armentrout, B. S.

Junior Farm Economist

HORTICULTURE

M. J. Dorsey, Ph. D.

H. L. Crane, M. S. Agr.

Horticulturist

Associate Horticulturist H. E. Knowlton, Ph. D.

Associate Horticulturist K. C. Westover, M. S. Agr.***

Assistant Horticulturist Ernest Angelo, B. S. Agr.

Junior Horticulturist

L. F. Sutton, B. S. Agr. $†$

Assistant Horticulturist Troy M. Currence, B. S. Agr.

Assistant in Horticulture Lewis G. Stark, B. S. Agr.

Assistant in Horticulture

PLANT PATHOLOGY

N. J. Giddings, Ph. D.

Anthony Berg, B. S.

Plant Pathologist

Assistant Plant Pathologist

L. H. Leonian, Ph. D.

Assistant Plant Pathologist

E. C. Sherwood, M. S.

Assistant Plant Pathologist

POULTRY HUSBANDRY

Horace Atwood, M. S. Agr.

Poultry Husbandman

SOILS

E. P. Deatrick, Ph. D.

Associate Soil Technologist

*In co-operation with the U. S. Department of Agriculture, Washington, D. C.

* In co-operation with the State Department of Agriculture, Charleston, W. Va.

***On leave of absence.

tIn charge of the Reymann Memorial Farms, Wardensville, W. Va.

$\$$ In charge of the Magrie Sub-Station, Maggie, W. Va. 


\section{FEEDING EXPERIMENTS WITH GRADE BEEF COWS RAISING CALVES*}

The work reported in this bulletin is part of a series of beefsattle experiments that have been in progress since December 2, 1914. They have been carried on cooperatively by the iureau of Animal Industry of the United States Department of griculture and the West Virginia Agricultural Experiment Staon, on the farm of David Tuckwiller, in Greenbrier County, Vest Virginia, to study beef-production problems in the Appachian Mountain region.* This farm is located in the southastern part of the state in the blue-grass area. The results of nis experiment apply not only to West Virginia, but also to the djacent states having similar conditions, as shown in the out-

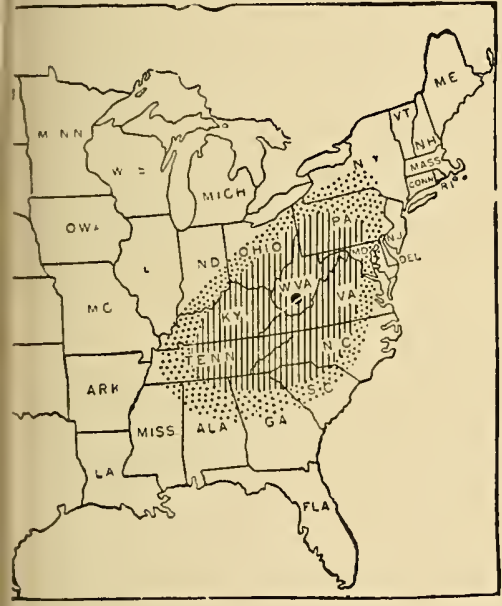

ig. 1.-Region to Which This Work Applies. The Black Dot Indicates the Location of the Farm on Which the Experiment Was Conducted. The Shaded Portion Represents the Area to Which the Results Are Applicable, and the Dotted Portion Shows an Additional Area to Which the Results Apply in Part. line map (Fig. 1). Some of the methods are so generally applicable that the results may be utilized to advantage by cattle raisers in other parts of the country.

\section{The Region and Its Problems}

The topography in most of the region, except in the vicinity of streams, is gently rolling or even mountainous in the higher elevations. The area is generally cleared of forest trees, although vast areas of cut-over or stump land are found. The farms vary in size from less than 100 acres to more than 1,000 acres. The land is especially well adapted for grazing, and in most sections there is tillable land for the production of abundant crops for winter feed or other purposes.

In this general area are proluced a large percentage of the grass-finished cattle which go innually to eastern markets. The fact that most of the steers oroduced in this area are finished for market on grass alone at-

* This work was started by the senior author while head of the Animal Husbandry Deartment of the West Virginia Arricultural Experiment Station, at which time the junior luthor was employed co-operatively by the Bureau of Animal Industry, and the West Virinia Agricultural Experiment Station, and which position he still holds. The senior author $s$ now chief of the Animal Husbandry Division. Bureau of Animal Indistry. United States Jepartment of Arriculture. 
tests the value of the pastures, which consist largely of blue grass The use of grain for finishing cattle is not general, although the practice is followed in some sections, particularly in the val. leys of the larger streams.

As a rule most grazers and feeders of beef steers do not raise calves to supply their needs for stockers. One of their chief problems, therefore, is to obtain calves, yearling steers or two-year-old steers of suitable beef type to use their feed to the best advantage. Many farmers keep only a small number of cows to produce milk and butter for their families. Some of them keep good beef cows, breed them to good bulls, and raise good calves by giving them a large part of the cows' milk. Others keep cows of the dairy type or of mixed dairy breeding, and breed them to either nondescript or dairy bulls. Calves from such breeding, as a rule, make' undesirable stockers. When they are poorly fed, as is often the case, they are even more undesirable. When good purebred beef bulls are used on such cows fairly good stocker calves can be raised. The best calves, however, are produced by the use of good beef cows, kred to good purebred beef bulls. There is a ready market for the latter type of calves arnong those who graze and feed stockers or older cattle.

Since the tendency of many small farmers seems to be to keep only a few cows that produce large quantities of milk, the cattle grazers and feeders in this area may be forced to raise their own calves as the business of feeding cattle grows and the demand for a better class of cattle increases. The questions then arise, what does it cost to keep a cow of good beef type solely for the calf she may raise, and how may she be fed most economically?

\section{Objects and Plan of the Work}

The experimental work reported in this bulletin was undertaken with the following objects:

1.- To determine the most satisfactory and economical method of wintering beef cows to raise calves.

2.-To find the cost of raising the calves.

The work was carried on for a period of four years, in order to have an average of feeds, cattle, seasons, and other conditions tending to produce variation. The general plan of the experiment is given in Table I. 
TABLE I.-Plan of the Four Years' Work.

Z

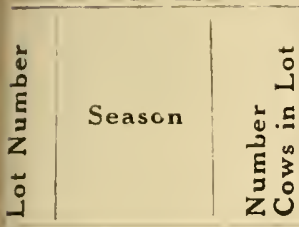

$1\left\{\begin{array}{l}1915-16 \\ 1916-17\end{array}\right.$

$1917-18$

19) $18-19$

$\left\{\begin{array}{l}1916-17 \\ 1917-18\end{array}\right.$

$1917-18\}$

1918-19

1915-16

$3\{1916-17$

$1917-18$

$1918-19$

$1915-16$
10

10

10

10

10

10

10

10

10

10

10
Winter Feed

Corn silage, mixed hay, and wheat straw.

Corn silage, mixed hay, and wheat straw.

Corn silage, mixed hay, and wheat straw.

Corn silage, mixed hay, and wheat straw.

Corn silage, soy-bean hay, and wheat straw.

Corn silage, soy-bean hay, and wheat straw.

Corn silage, soy-bean hay, and wheat straw.

Corn silage,cottonseed meal, and wheat straw

Corn silage,cottonseed meal, and wheat straw

Corn silage,cottonseed meal,and wheat straw

Corn silage,cottonseed meal,and wheat straw

10 Shock corn, mixed hay, and wheat straw.... Pasture

*Orixinally it was planned to feed shock corn, mixed hay, and wheat straw to Lot 4 hroughout the experiment, but because the ration, was so much more expensive than the ilage rations and because it dis not maintain the cows so well as the silage rations it was bandoned after the first year.

\section{Description of Cows}

The cows used were grades of the Shorthorn, Hereford, and Aberdeen-Angus breeds. (See Figs. 3, 4, and 5.) In the fall of the first year the cows, which were bred to calve in the spring or early summer, were bought in the surrounding section. While most of the cows had been bred to purebred bulls, a few had been bred to high-grade bulls. During the following years as

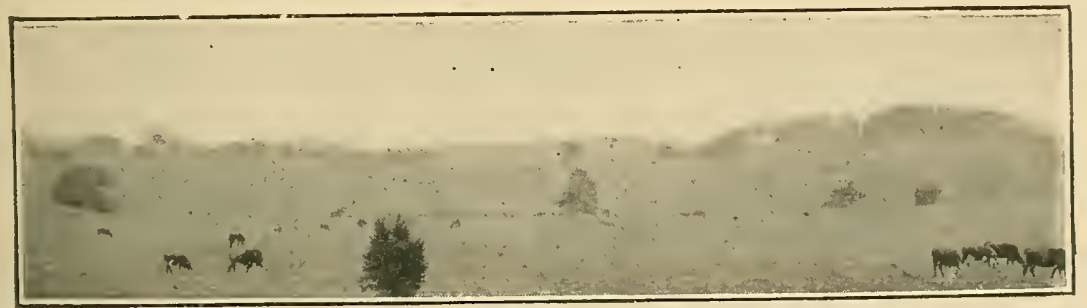

Fig. 2.-Character of the Land and Pasture.

many as possible of these cows were bred during the summer to a purebred bull. As some of them failed to get with calf early enough to provide a uniform lot of calves, other cows and heifers were used to replace them: 


\section{Feeds Used}

Samples of the feeds were taken at different times during the winter periods and sent to the Department of Chemistry West Virginia Agricultural Experiment Station, Morgantown West Virginia, to be analyzed. The averages of these analyses are shown in Table II, in heavy type, while the average analyses for several thousand samples, as computed by the United States Department of Agriculture, are shown in ordinary type.

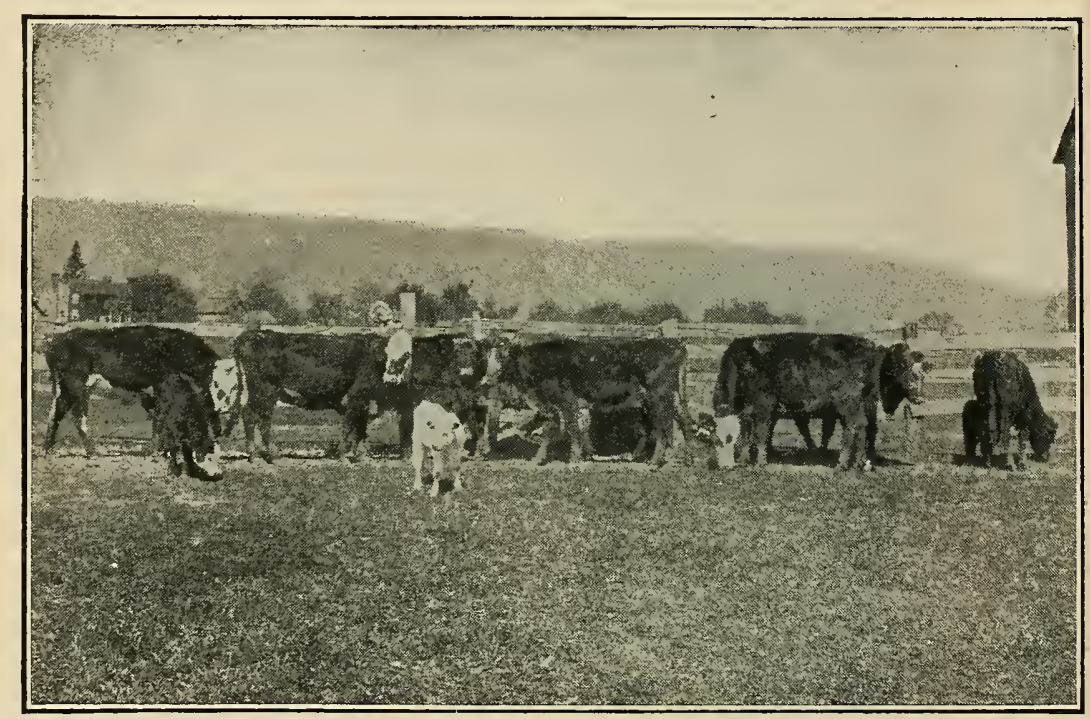

Fig. 3.-Lot 1. Cows Fed Corn Silage, Mixed Hay, and Wheat Straw, at: the End of the Winter Period, April 25, 1919.

TABLE II.-Compositions of Feeds Used.

\begin{tabular}{|c|c|c|c|c|c|}
\hline Feeds & U⿺辶ّ & 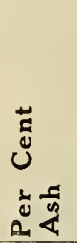 & 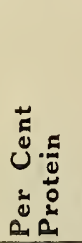 & 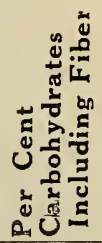 & 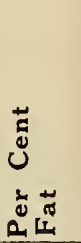 \\
\hline Corn silage .... & 75.0 & 1.1 & 1.9 & 21.5 & 0.5 \\
\hline Mixed Hay ... & $\begin{array}{r}70.9 \\
8.3\end{array}$ & $\begin{array}{l}1.4 \\
3.7\end{array}$ & $\begin{array}{l}2.4 \\
6.6\end{array}$ & $\begin{array}{l}24.4 \\
79.5\end{array}$ & $\begin{array}{l}0.9 \\
1.9\end{array}$ \\
\hline Wheat straw & 8.4 & 3.2 & 2.9 & 84.1 & 1.4 \\
\hline Soybean hay & 9.6 & 4.2 & 3.4 & 81.5 & 1.3 \\
\hline soyoean nay & $\begin{array}{l}9.0 \\
8.4\end{array}$ & $\begin{array}{l}9.1 \\
8.9\end{array}$ & $\begin{array}{l}10.0 \\
15.8\end{array}$ & $\begin{array}{l}68.9 \\
63.1\end{array}$ & $\begin{array}{l}3.0 \\
3.8\end{array}$ \\
\hline Cottonseed meal & 7.8 & 6.0 & 37.6 & 40.3 & 8.3 \\
\hline Shock corn ....... & $\begin{array}{r}7.3 \\
11.8\end{array}$ & $\begin{array}{l}5.8 \\
5.8\end{array}$ & $\begin{array}{r}36.8 \\
7.4\end{array}$ & $\begin{array}{l}43.5 \\
72.6\end{array}$ & $\begin{array}{l}6.6 \\
2.4\end{array}$ \\
\hline
\end{tabular}


From the analyses it is evident that the feeds used, with the exception of cottonseed meal, were somewhat below the average in quality. The cottonseed meal used was a little better than the average cottonseed meal graded as "good" by the Association of Feed Control Officials of the United States.

\section{Feed Crops in the Region}

A three-year rotation of crops, consisting of corn, wheat, and hay, is practiced rather generally in the region under discussion. Timothy is sown with the wheat in the fall, and red clover is sown on the same field in the spring. This provides in the year following the wheat crop a mixed hay of approximately one-half timothy and one-half clover. In making soybean hay the ground is prepared about as it would be for corn. The beans are drilled broadcast, using one and one-half bushels per acre. They are usually sown the last of May or the first of June, after all danger of heavy frost is past. When the beans begin to form in the pods, about the first of September, the time varying with the variety of beans and the kind of season, the crop is cut and cured for hay.

\section{Kind of Pasture}

Each year the cows and their calves were turned on a pasture of about one hundred and twenty acres.

The soil is of limestone formation and a good growth of blue grass with much white clover is found on all parts of the pasture, which is typical of this section. Under normal climatic conditions there is rainfall enough to keep the grass growing throughout the season.

\section{Method of Feeding and Handling}

In the fall, before being started on the winter feed, the cows were divided into lots of ten each. In this division care was taken to have the lots as uniform as possible in quality, breeding, size, and condition. These different lots were allowed the same amount of space in open sheds with small outside lots about 25 by 50 feet in size. Water was supplied in these lots at all times and salt was constantly available. The cows were fed twice a day.

The feed, both concentrates and roughages, was weighed at each feeding and accurate records kept of the quantities fed. 
The cows were weighed individually at the beginning, and at the end of the winter feeding period, the weights being taken three days in succession and the averages taken as their initial and final weights. They were also weighed once every twenty-eight days. The weights were taken in the morning after feeding. For identification, neck straps with numbers on them were used.

After the cows were turned on grass in the spring it was necessary in some instances where the cows gave a heavy flow of milk to give the calves only a part of the milk until they were old enough to take it all.

\section{RATIONS, GAINS AND LOSSES IN WEIGHT, AND CALVES PRODUCED}

\section{Feed Consumed}

These cows received only enough feed to keep them in good, strong, thrifty condition. As the graph in Figure 7 shows, they gained in weight until they calved.

Table III shows the total amount of feeds consumed by the various lots and the average ration per cow in each lot for the four winters.

\section{TABLE III.-Average Total and Daily Rations During Four Winters.}

\begin{tabular}{|c|c|c|c|c|c|c|c|c|c|c|}
\hline \multirow[b]{2}{*}{$\begin{array}{l}\text { Lot Number } \\
\text { and Ration }\end{array}$} & \multicolumn{4}{|c|}{ Tatal Feed per Cow in Lbs. } & \multicolumn{3}{|c|}{ Daily Feed } & \multicolumn{2}{|c|}{ per Cow in } & Lbs. \\
\hline & 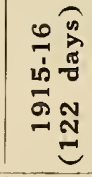 & 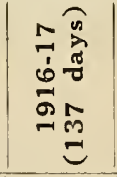 & 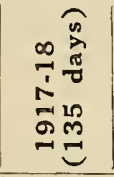 & 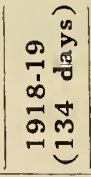 & $\begin{array}{l}0 \\
\text { on } \\
0 \\
0 \\
0 \\
0 \\
4\end{array}$ & 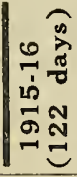 & 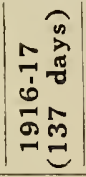 & 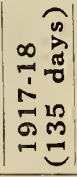 & 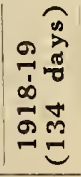 & $\begin{array}{l}0 \\
\text { on } \\
\frac{\pi}{0} \\
0 \\
3 \\
4\end{array}$ \\
\hline Lot 1: & & & & & & & & & & \\
\hline Corn silage & 2,440 & 3,398 & 2,889 & 3,480 & 3,052 & 20 & 24.8 & 21.4 & 26.0 & 23.1 \\
\hline Mixed hay & 976 & 1,096 & 977 & 1,094 & 1,036 & 8 & 8 & 7.2 & 8.2 & 7.8 \\
\hline Wheat straw & 334 & 367 & 338 & 355 & 348 & 2.7 & 2.7 & 2.5 & 2.6 & 2.6 \\
\hline Lot 2: & & & & & & & & & & \\
\hline Corn silage & & 3,398 & 2,889 & 3,480 & 3,256 & & 24.8 & 21.4 & 26.0 & 24.1 \\
\hline Soybean hay. & & 1,096 & 945 & 960 & 1,000 & & 8 & 7 & 7.2 & 7.4 \\
\hline Wheat straw & & 225 & 324 & 355 & 301 & & 1.6 & 2.4 & 2.6 & 2.2 \\
\hline Lot 3: & & & & & & & & & & \\
\hline Corn silage & 3,050 & 3,398 & 2,889 & 3,480 & $|3,204|$ & 25 & 24.8 & 21.4 & 26.0 & 24.3 \\
\hline Cottonseed meal & 183 & 205.5 & 202.5 & 201 & 198 & 1.5 & 1.5 & 1.5 & 1.5 & 1.5 \\
\hline Wheat straw & 976 & 995 & 864 & 960 & 949 & 8 & 7.3 & 6.4 & 7.2 & 7.2 \\
\hline $\begin{array}{l}\text { Lot 4: } \\
\text { Shock corn }\end{array}$ & & & & & & & & & & \\
\hline $\begin{array}{l}\text { Shock corn } \\
\text { Mixed hay ... }\end{array}$ & $\left|\begin{array}{l}1,830 \\
1,220\end{array}\right|$ & & & & & $\begin{array}{l}15 \\
10\end{array}$ & & & & \\
\hline Wheat straw .... & 224 & & & & & 1.8 & & & & -...- \\
\hline
\end{tabular}


The composition and the nutritive ratio of the rations fed are given in Table IV.

\section{TABLE IV.-Quantities of Dry Matter and Digestible Nutrients in the Feeds, and Nutritive Ratios of the Rations.}

\begin{tabular}{|c|c|c|c|c|c|c|}
\hline 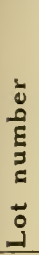 & Rations & 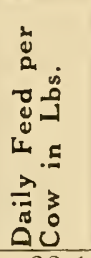 & 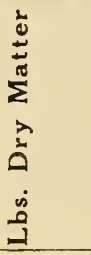 & 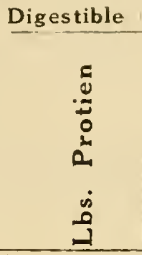 & 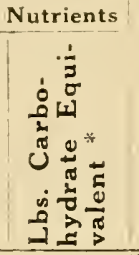 & 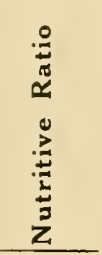 \\
\hline 1 & $\begin{array}{l}\text { Corn silage } \\
\text { Mixed hay } \\
\text { Wheat straw }\end{array}$ & $\begin{array}{r}23.1 \\
7.8 \\
2.6\end{array}$ & $\begin{array}{l}5.77 \\
7.15 \\
2.35\end{array}$ & $\begin{array}{r}0.32 \\
.45 \\
.10\end{array}$ & $\begin{array}{r}4.37 \\
3.43 \\
.97\end{array}$ & \multirow[t]{2}{*}{$1: 10.1$} \\
\hline \multirow{3}{*}{2} & & & 15.27 & .87 & 8.77 & \\
\hline & $\begin{array}{l}\text { Corn silage } \\
\text { Soybean hay } \\
\text { Wheat straw ... }\end{array}$ & $\begin{array}{r}24.1 \\
7.4 \\
2.2\end{array}$ & $\begin{array}{l}6.02 \\
6.73 \\
1.99\end{array}$ & $\begin{array}{l}.34 \\
.83 \\
.01\end{array}$ & $\begin{array}{r}4.55 \\
3.26 \\
.82\end{array}$ & \multirow[t]{2}{*}{$1: 7.3$} \\
\hline & & & 14.74 & 1.18 & 8.63 & \\
\hline \multirow[t]{2}{*}{3} & $\begin{array}{l}\text { Corn silage } \\
\text { Cottonseed meal } \\
\text { Wheat straw }\end{array}$ & $\begin{array}{r}24.3 \\
1.5 \\
7.2\end{array}$ & $\begin{array}{l}6.07 \\
1.38 \\
6.51\end{array}$ & $\begin{array}{l}.34 \\
.46 \\
.03\end{array}$ & $\begin{array}{r}4.59 \\
.63 \\
2.67\end{array}$ & \multirow[t]{2}{*}{$1: 9.5$} \\
\hline & & ........ & 13.96 & .83 & 7.89 & \\
\hline \multirow[t]{2}{*}{4} & $\begin{array}{l}\text { Shock corn } \\
\text { Mixed hay } \\
\text { Wheat straw }\end{array}$ & $\begin{array}{r}15.0 \\
10.0 \\
1.8\end{array}$ & $\begin{array}{r}13.23 \\
9.17 \mid \\
1.63\end{array}$ & $\begin{array}{l}.61 \\
.58 \\
.01\end{array}$ & $\begin{array}{r}8.34 \\
4.39 \\
.67\end{array}$ & \multirow[t]{2}{*}{$1: 11.2$} \\
\hline & & & 24.03 & 1.20 & 13.40 & \\
\hline
\end{tabular}

*The carbohydrate equivalent is the sum of the digestible carbohydrates plus 2.25 times the digestible fat.

\section{Calves Produced and Their Birth Weights}

Table $\mathrm{V}$ shows the number of calves born and raised in each lot each season, with the average weight at birth of each lot. The table shows that, in 1915-16, thirty calves were dropped, two of which died. In 1916-17 the cows were sold at the end of the winter feeding period. In 1917-18, twenty-seven calves were dropped, one of which died. In 1918-19, twenty-nine of the cows dropped calves and raised all of them.

Most of the calves were dropped in April and May and a few in March and June, one-half of them being dropped before the cows were turned to pasture and the other half after. The 


\section{TABLE V.-Numbers and Birth Weights of Calves}

\section{Produced by Each Lot of Cows.}

\begin{tabular}{|c|c|c|c|c|c|}
\hline 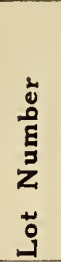 & Rations & 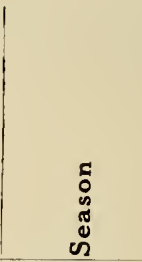 & 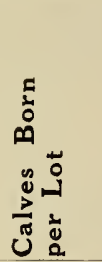 & 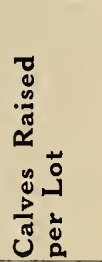 & 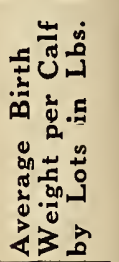 \\
\hline \multirow[t]{2}{*}{1} & $\begin{array}{l}\text { Corn silage, mixed hay, } \\
\text { and straw ................. }\end{array}$ & $\left\{\begin{array}{l}1915-16 \\
1917-18 \\
1918-19\end{array}\right.$ & $\begin{array}{r}10 \\
9 \\
10\end{array}$ & $\begin{array}{r}10 \\
9 \\
10\end{array}$ & $\begin{array}{l}62.9 \\
70.3 \\
64.6\end{array}$ \\
\hline & Average & & 9.7 & 9.7 & 65.8 \\
\hline \multirow[t]{2}{*}{2} & $\begin{array}{l}\text { Corn silage, soybean hay, } \\
\text { and straw }\end{array}$ & $\left\{\begin{array}{l}1917-18 \\
1918-19\end{array}\right.$ & $\begin{array}{r}10 \\
9\end{array}$ & $\begin{array}{r}10 \\
9\end{array}$ & $\begin{array}{l}62.8 \\
73.0\end{array}$ \\
\hline & Average ............. & & 9.5 & 9.5 & 67.6 \\
\hline \multirow[t]{2}{*}{3} & $\begin{array}{l}\text { Corn silage, straw, and } \\
\text { cottonseed meal }\end{array}$ & $\left\{\begin{array}{l}1915-16 \\
1917-18 \\
1918-19\end{array}\right.$ & $\begin{array}{r}10 \\
8 \\
10\end{array}$ & $\begin{array}{r}9 \\
7 \\
10\end{array}$ & $\begin{array}{l}67.0 \\
64.6 \\
64.6\end{array}$ \\
\hline & Average & & 9.3 & 8.7 & 65.4 \\
\hline 4 & $\begin{array}{l}\text { Shock corn, mixed hay, } \\
\text { and straw }\end{array}$ & $1915-16$ & 10 & 9 & 61.1 \\
\hline
\end{tabular}

average date on which the calves were dropped was April 20. The average per cent of calves raised by the three lots of 10 cows each for three years was 92 . Such numbers of calves can not be produced from 30 cows year after year if the same cows are kept. In these tests if the cows did not become settled in calf so as to drop calves at the desired time, others were substituted.

While the average birth weight of the calves of Lot 2, which, according to Table III, was fed considerably more digestible protein than Lots 1 and 3 , is two pounds more, this may not be significent, because it averaged less than the birth weights of the other lots in 1917-18.

The smallest average birth weight, that of the calves of Lot 4 , may be due to the lack of succulence in the ration, yet the difference does not seem significant, as it is small and represents only one year's work.

\section{Gains and Losses in Weight}

Table VI shows the gains or losses of each lot during the winter periods. The main fact shown in this table is that all the 
different lots of cows, except in 1915-16, gained from twenty io seventy five pounds from the beginning of the feeding period in December until they were turned on pasture. In 1915-16 the silage fed lots lost weight because the silage was of poor quality, part of it being made from silage corn, and because they got less feed in proportion to their weight. As Lot 4, fed shock corn, according to Table III received more protein and considerably more carbohydrates than Lots 1 and 3 , their loss in weight is attributed to the lack of succulence in their ration. The average date on which the cows were turned to pasture was April 22, two days later than the average date on which the calves were dropped.

The last two columns of Table VI give the number of calves dropped in each lot during the winter period and their average age at the end of that time.

During each year some of the cows calved during the latter part of the winter feeding period and the others after they were

\section{TABLE VI.-Results During Four Winters.}

\begin{tabular}{|c|c|c|c|c|c|c|c|c|}
\hline 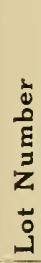 & Rations & 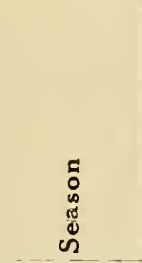 & 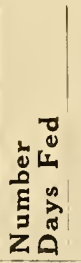 & 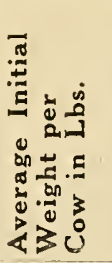 & 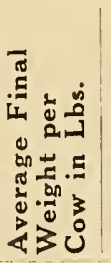 & 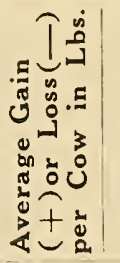 & 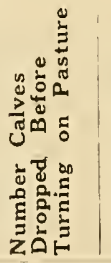 & 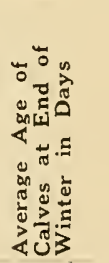 \\
\hline \multirow[t]{5}{*}{1} & \multirow{4}{*}{$\begin{array}{l}\text { Corn silage, mixed } \\
\text { hay, and wheat } \\
\text { straw }\end{array}$} & \multirow{5}{*}{$\begin{array}{l}1915-16 \\
1916-17 \\
1917-18 \\
1918-19\end{array}$} & 122 & 865 & 779 & -86 & 6 & 30 \\
\hline & & & 137 & 855 & 879 & +24 & & \\
\hline & & & 134 & 740 & 766 & +26 & 1 & 15 \\
\hline & & & 134 & 858 & 879 & +21 & 5 & 38 \\
\hline & Average............ & & 132 & 830 & 826 & -4 & & \\
\hline \multirow[t]{4}{*}{2} & \multirow{4}{*}{$\begin{array}{l}\text { Corn silage, soy- } \\
\text { bean hay, and } \\
\text { wheat straw. }\end{array}$} & \multirow{4}{*}{$\begin{array}{l}1916-17 \\
1917-18 \\
1918-19\end{array}$} & 137 & 829 & 870 & +41 & & \\
\hline & & & 134 & 740 & $789 \mid$ & +49 & 3 & $\ldots 4$ \\
\hline & & & 134 & 857 & 909 & +52 & 6 & 28 \\
\hline & & & 135 & 809 & 856 & +47 & & \\
\hline \multirow[t]{4}{*}{3} & \multirow{3}{*}{$\begin{array}{l}\text { Corn silage, cot- } \\
\text { tonseed meal, } \\
\text { and wheat straw. }\end{array}$} & \multirow{4}{*}{$\begin{array}{r}1915-16 \\
1916-17 \\
1917-18 \\
1918-19\end{array}$} & 122 & 870 & 835 & -35 & 8 & 23 \\
\hline & & & 137 & $\begin{array}{r}849 \\
733\end{array}$ & $\begin{array}{r}873 \\
808\end{array}$ & $\begin{array}{l}+24 \\
+75\end{array}$ & 3 & \\
\hline & & & 134 & 857 & 873 & +16 & 6 & 33 \\
\hline & Average... & & 132 & 827 & 847 & +20 & & \\
\hline 4 & $\begin{array}{l}\text { Shock corn, mixed } \\
\text { hay, and wheat } \\
\text { straw. }\end{array}$ & $1915-16$ & 122 & 867 & 818 & -49 & 5 & 27 \\
\hline
\end{tabular}


turned on grass. A cow loses considerable weight when she drops a calf and continues to lose weight for several weeks, especially if she is milking heavily. Consequently, differences in lot weights at calving time are not a satisfactory basis for conclusions. Lot 3 , receiving silage, straw, and cottonseed meal, seemed to stay in the best condition through the winter.

Table VII shows the gains or losses per cow made during summer and winter periods and net gain for the year period. The chief value of this table is that it shows what gains may be made by cows on grass while they are suckling calves. It also shows that the lots which lost in weight during the winter made greater gains during the following summer than the lots which had maintained their weight through the winter. However, the lots which had maintained their weight through the winter made greater gains for the whole year than the lots which had lost in weight during the winter.

TABLE VII.-Gains and Losses During Two Summers on

Pasture and Total Gain for Winter and Summer.

\begin{tabular}{|c|c|c|c|c|c|c|c|c|}
\hline \multirow[b]{2}{*}{ 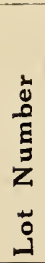 } & \multirow[b]{2}{*}{ Season } & \multirow[b]{2}{*}{ 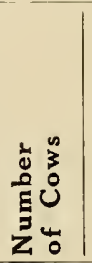 } & \multirow[b]{2}{*}{ 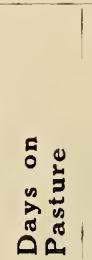 } & \multicolumn{2}{|c|}{$\begin{array}{l}\text { Weights on } \\
\text { Pasture }\end{array}$} & \multicolumn{3}{|c|}{$\begin{array}{l}\text { Gain }(+) \text { or Loss }(-) \\
\text { per Cow in Lbs. }\end{array}$} \\
\hline & & & & 递 & 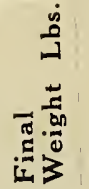 & 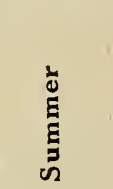 & $\frac{\stackrel{D}{ \pm}}{3}$ & 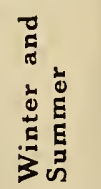 \\
\hline \multirow[t]{2}{*}{1} & $\begin{array}{l}1915-16 \\
1917-18\end{array}$ & \multirow[t]{2}{*}{$\begin{array}{l}10 \\
10\end{array}$} & \multirow[t]{2}{*}{$\begin{array}{l}140 \\
140\end{array}$} & $\begin{array}{l}779 \\
766\end{array}$ & $\begin{array}{l}916 \\
761\end{array}$ & $\begin{array}{r}+137 \\
-5\end{array}$ & $\begin{array}{l}-86 \\
+26\end{array}$ & $\begin{array}{l}+51 \\
+21\end{array}$ \\
\hline & Average & & & 772 & 838 & +66 & -30 & +36 \\
\hline 2 & $1917-18$ & \multirow{3}{*}{$\begin{array}{l}10 \\
10\end{array}$} & 140 & 789 & 789 & & +49 & +49 \\
\hline \multirow[t]{2}{*}{3} & $\begin{array}{l}1915-16 \\
1917-18\end{array}$ & & \multirow[t]{2}{*}{$\begin{array}{l}140 \\
140\end{array}$} & $\begin{array}{l}835 \\
808\end{array}$ & $\begin{array}{l}916 \\
803\end{array}$ & $\begin{array}{l}+81 \\
-5\end{array}$ & $\begin{array}{l}-35 \\
+75\end{array}$ & $\begin{array}{l}+46 \\
+70\end{array}$ \\
\hline & Average & & & 821 & 859 & +38 & +20 & +58 \\
\hline 4 & $1915-16$ & 10 & 140 & 818 & 877 & +59 & -49 & +10 \\
\hline
\end{tabular}

\section{Graphic Presentation of Monthly Weights}

The gains and losses in :weight from month to month made by each lot of cows during 1915-16 and 1917-18 are shown graphically in Figure 7. 


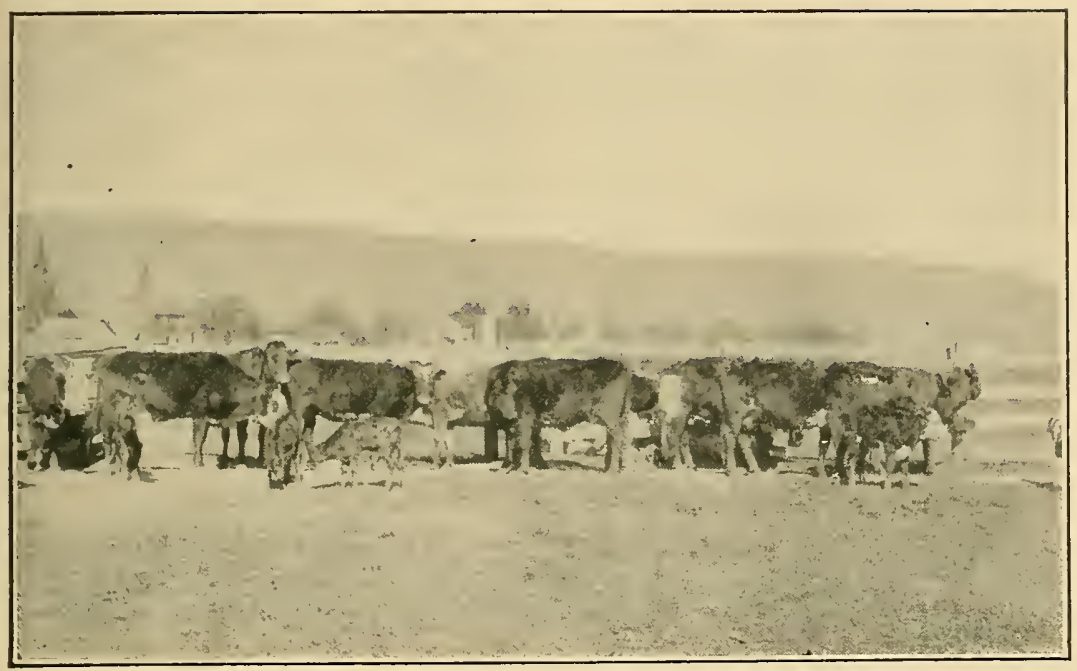

Fig. 5.-Lot 3. Cows Fed Corn Silage, Cottonseed Meal, and Wheat Straw, at the End of the Winter Period, April 25, 1919.

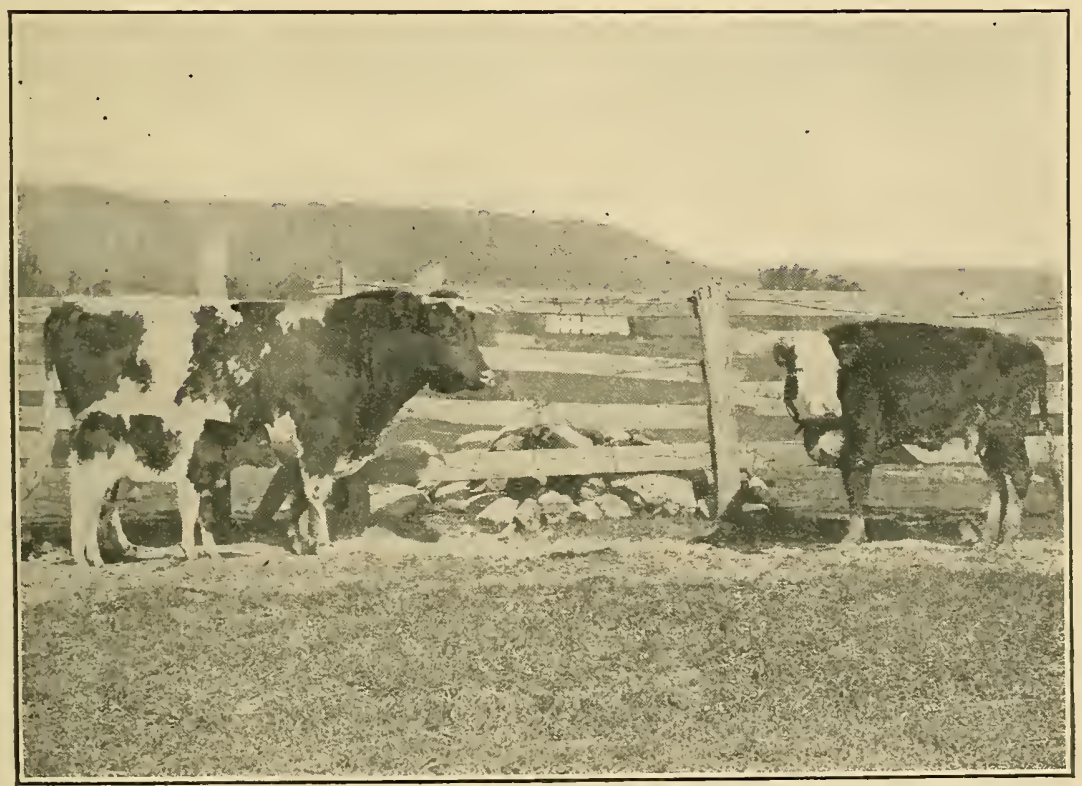

Fig. 6.-Sire, Dam, and Offspring. The Sire is the Registered Shorthorn Bull to Which the Cows, Used in This Experiment, Were Bred. Note the Prepotency of the Purebred Sire as Indicated by the Calf. 
Arerage length of feeding period.

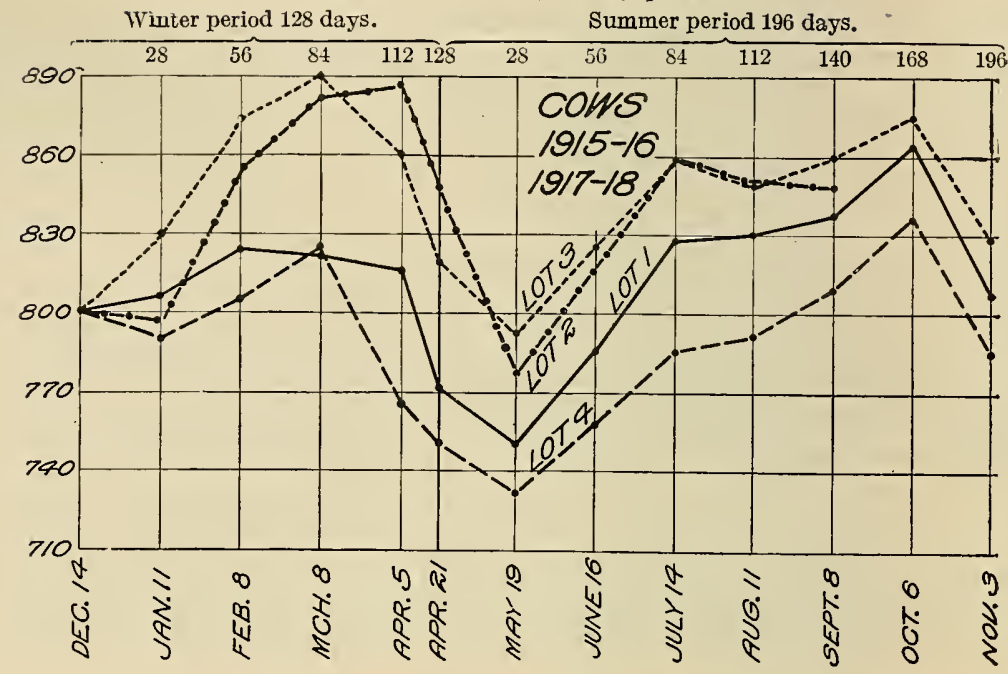

Fig. 7.-Gains and Losses in Weight of Cows.

The horizontal distance on the chart indicates the number of days the cows were fed during the winters and pastured during the summers. The average length of the total period for the itwo years was 324 days, of which 128 days were in the winter period and 196 in the summer period. The heavy, black, vertical line near the center of the chart marks the dividing line between the winter/and summer periods. Vertical distance represents changes in live weight of the cows as indicated by the figures along the left side of the chart. The curves for the cows of Lots 1 and 3 represent an average of two years' feeding, while those for Lots 2 and 4 represent only one year's feeding. Figure 8, showing the gains made by the calves is based on the feeding year 1915-16 alone, because no complete records were obtained for 1916-17, 1917-18, and 1918-19, the calves having been sold before the end of the summer periods.

Since the average weight of the cows for 1915-16 and 191718 was 799 pounds, all the lots are started at the 800 -pound line to make them more readily comparable. The time of beginning the winter period and the length of it are also averaged, to have the graphs on a uniform basis. The!winter period in 1915-16 began December 22 and lasted 122 days, while the winter period in 1917-18 began December 7 and lasted 134 days. This makes the average time of beginning the winter period 
December 14, and the average length of the last section of the winter period 16 days.

In studying the variations in the weights of the cows from month to month, it should be kept in mind that the average time of calving for the two years represented in Figure 7 was practically the same as the time when cows were turned on to pasture.

The average birth date of the 19 calves of Lot 1 during 1915-16 and 1917-18 was two days after the cows were turned on pasture; for the ten calves of Lot 2 in 1917-18, seven days

Average length of feeding period.

Winter period 128 days.

Summer period 224 days.

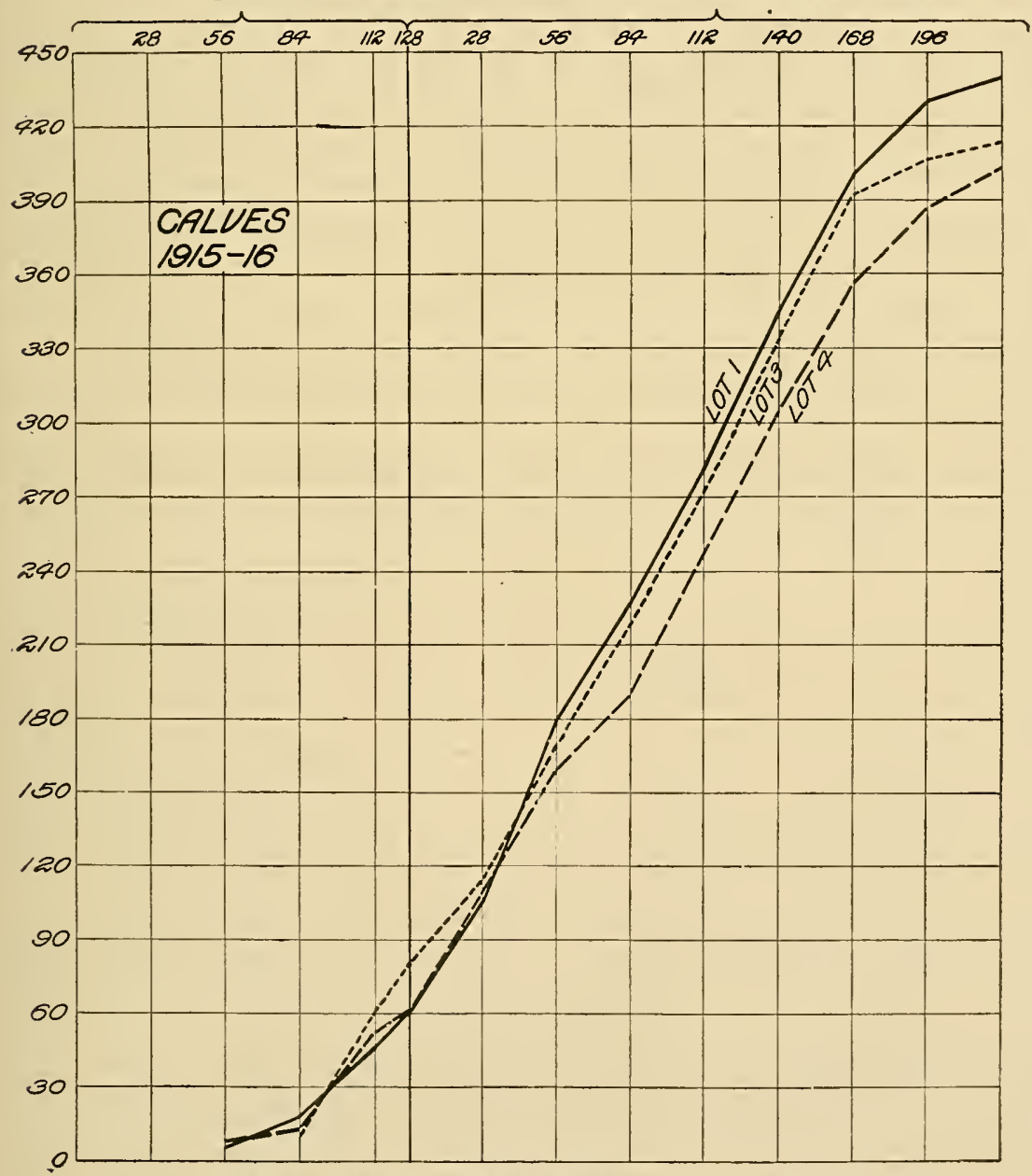

Fig. 8.-Gains of Calves, Season of 1915-16. 
before; for the sixteen, calves of Lot 3 in 1915-16 and 1917-18, six days after; and for the ten calves of Lot 4 in 1915-16, one and a half days after.

Figure 8 shows how the calves gained in weight during 1915-16. The average weight of the calves for each weight day, designated by the vertical lines, was obtained by dividing the total weight of the calves in each lot by the number of cows in each lot. It should be kept in mind here that most of the calves were dropped in April and in May and that about onehalf were dropped before and the other half after the cows were turned on pasture.

Figure 7 shows that the cows gained in weight during the winter period until they began to drop calves. This is generally expected in wintering beef cows. The cows lost in weight during the rest of the winter and continued to lose weight during the first twenty-eight days on pasture. During the following fifty-six days they gained in weight rapidly, following which for the next fifty-six days they about maintained their weight. Then, when it was cooler and they began to dry up, they gained in weight, but lost heavily in October, when rains and frost usuallyllower the feeding value of pasture considerably.

The calves gained in weight very uniformily until October,

TABLE VIII.-Summary of Feed Consumed per 1,000 Pounds Live Weight of Cow, and per Calf Raised to Weaning Age.

\begin{tabular}{|c|c|c|c|c|}
\hline \multirow{2}{*}{ 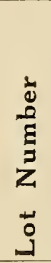 } & \multirow{2}{*}{ Rations } & \multicolumn{2}{|c|}{$\begin{array}{l}\text { Feed per } 1,000 \\
\text { Lbs. Live Weight } \\
\text { of Cow }\end{array}$} & \multirow{2}{*}{ 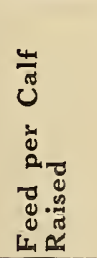 } \\
\hline & & 㺃官 & 䒕告 & \\
\hline 1 & $\begin{array}{l}\text { Corn silage .......... } \\
\text { Mixed hay .......... } \\
\text { Wheat straw }\end{array}$ & $\begin{array}{r}3,688 \\
1,252 \\
421\end{array}$ & $\begin{array}{r}27.9 \\
9.5 \\
3.2\end{array}$ & $\begin{array}{r}3,038 \\
1,051 \\
354\end{array}$ \\
\hline 2 & $\begin{array}{l}\text { Corn silage } \\
\text { Soybean hay ........ } \\
\text { Wheat straw }\end{array}$ & $\begin{array}{r}3,911 \\
1,201 \\
362\end{array}$ & $\begin{array}{r}28.9 \\
8.9 \\
2.7\end{array}$ & $\begin{array}{r}3,352 \\
1,003 \\
357\end{array}$ \\
\hline 3 & $\begin{array}{l}\text { Corn silage } \\
\text { Wheat straw } \\
\text { Cottonseed meal }\end{array}$ & $\begin{array}{r}3,830 \\
1,134 \\
237\end{array}$ & $\begin{array}{r}29.0 \\
8.6 \\
1.8\end{array}$ & $\begin{array}{r}3,623 \\
1,077 \\
226\end{array}$ \\
\hline 4 & $\begin{array}{l}\text { Shock corn } \\
\text { Mixed hay } \\
\text { Wheat straw }\end{array}$ & $\begin{array}{r}2,172 \\
1,448 \\
266 \\
\end{array}$ & $\begin{array}{r}17.8 \\
11.9 \\
2.2 \\
\end{array}$ & $\begin{array}{r}2,033 \\
1,356 \\
249 \\
\end{array}$ \\
\hline
\end{tabular}


when the smaller amount of milk given by the cows and the poorer pasture, caused the rate of gain to be somewhat less.

\section{Feeds Consumed per 1,000 Pounds Live Weight and per Calf Raised}

Table VIII is for the convenience of those who may have larger or smaller cows than were used in this project and who may want to calculate how much feed will be required to winter the herd. In case the feeding period is longer or shorter than the one in this experiment, the column showing the daily feed consumed per 1,000 pounds live weight may be used to advantage.

\section{Summary for Feeding and Handling}

For carrying an 834-pound grade beef cow that is to drop a calf in the spring or early summer through an average winter period of 132 days, the following quantities of feed per day were required to make the corresponding gains or losses in weight during the winter:

Lot 1. Corn silage
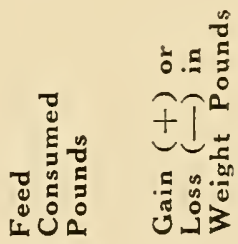

Lot 2. Corn silage

Mixed hay

Wheat straw

Soybean hay

Wheat straw

23.1

7.8

2.6

24.17

$2.2\}$

$+47$

24.3

1.5

7.2

Cottonseed meal

Wheat straw

15.0

10.0

Mixed hay

Wheat straw

1.8

The average birth weight of the calves and the gains in weight made during both winter and summer periods indicate that the above-mentioned rations should be ranked 2, 3, 1, and 4 . 
Unless cows which do not settle within three or four months after calving are replaced by bred cows or heifers, the breeder loses for the following reasons:

A smaller calf crop each year.

A lack of uniformity in the ages of the calves.

A greater labor, feed, and equipment cost if the calves are dropped in the fall or winter.

Greater inconvenience and cost in handling when all the calves do not come in one season.

It seems advisable for farmers raising grade beef calves to use as many two-year-old heifers as they can produce or purchase at a reasonable cost. Heifers raise good calves and at the same time make considerable gain in weight if they are fed properly. When the calves are weaned the heifers can be fattened, sold, and replaced by more two-year-olds. This gain in weight by growth can not be obtained in the case of aged cows.

\section{Cost of the Rations and of Raising Calves to Weaning Age}

The following comparisons are made to see which is the cheapest of the various rations used in the experiment, and especially to see with which one the calves were produced most cheaply.

\section{Prices Used}

For the purpose mentioned it is necessary to fix the prices for feeds on the farm. This is the most questionable and unsatisfactory part of such experimental work, especially for the last few years, during whuch unusual fluctuations have occurred in feed prices. On account of these fluctuations and also for simplicity in making the various calculations, an average of the feed prices for the three years is used, as follows:

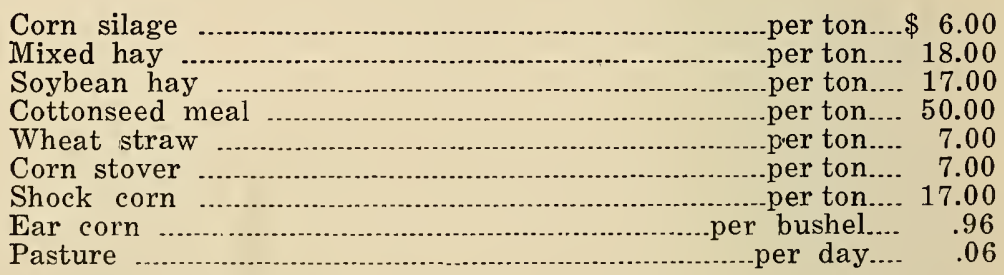

The foregoing figures are based on the average farm prices of corn and hay from 1910 to 1919, as given in the Yearbook of the United States Department of Agriculture, for the states of West Virginia, Virginia, Maryland, Pennsylvania, Ohio, Kentucky, Tennessee, and North Carolina. 
To determine which ration should be used in a particular feeding operation, it is suggested that the feeder apply local prices to the average amounts of the feeds consumed per cow, as given in Tables III and VIII.

TABLE IX. - Cost of Feeding the Cows During the Four Years and the Average Cost for Each Calf Raised to Weaning Age.

\begin{tabular}{|c|c|c|c|c|c|}
\hline 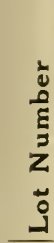 & Rations & $\begin{array}{l}\text { : } \\
0 \\
\text { d } \\
\text { ஸे }\end{array}$ & 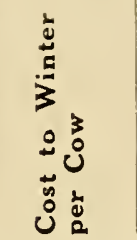 & 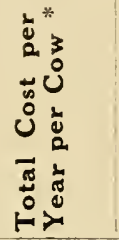 & 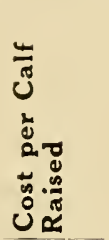 \\
\hline \multirow[t]{3}{*}{1} & \multirow{3}{*}{$\begin{array}{l}\text { Corn silage, mixed hay, } \\
\text { and wheat straw. }\end{array}$} & \multirow{3}{*}{$\begin{array}{l}1915-16 \\
1916-17 \\
1917-18 \\
1918-19\end{array}$} & $\$ 17.27$ & $\$ 31.91$ & $\overline{\$ 31.91}$ \\
\hline & & & $\begin{array}{l}18.64 \\
21.53\end{array}$ & $\begin{array}{l}32.44 \\
35.39\end{array}$ & $\begin{array}{l}36.04 \\
35.39\end{array}$ \\
\hline & & & 19.69 & 33.69 & 34.39 \\
\hline \multirow[t]{2}{*}{2} & \multirow[t]{2}{*}{$\begin{array}{l}\text { Corn silage, soybean hay } \\
\text { and wheat straw .................... }\end{array}$} & \multirow[t]{2}{*}{$\begin{array}{l}1916-17 \\
1917-18 \\
1918-19\end{array}$} & $\begin{array}{l}20.30 \\
17.83 \\
19.84\end{array}$ & $\begin{array}{l}33.98 \\
31.63 \\
33.70\end{array}$ & $\begin{array}{l}31.63 \\
37.44\end{array}$ \\
\hline & & & 19.32 & 33.10 & 34.38 \\
\hline \multirow[t]{3}{*}{3} & \multirow[t]{3}{*}{$\begin{array}{l}\text { Corn silage, cottonseed meal, } \\
\text { and wheat straw }\end{array}$} & \multirow{3}{*}{$\begin{array}{l}1915-16 \\
1916-17 \\
1917-18 \\
1918-19\end{array}$} & $\begin{array}{l}17.13 \\
18.81\end{array}$ & $\begin{array}{l}31.77 \\
32.49\end{array}$ & 35.30 \\
\hline & & & $\begin{array}{l}16.75 \\
18.83\end{array}$ & $\begin{array}{l}30.55 \\
32.69\end{array}$ & $\begin{array}{l}43.57 \\
32.69\end{array}$ \\
\hline & & & 17.88 & 31.87 & 36.54 \\
\hline 4 & $\begin{array}{l}\text { Shock corn, mixed hay, } \\
\text { wheat straw }\end{array}$ & $1915-16$ & 27.50 & 42.14 & 46.82 \\
\hline
\end{tabular}

* The cost of keeping a cow a year in this table is for 365 days, instead of for the winter period of 132 days and 140 days in summer while suckling calves, as reported in Tables VI. and VII.

\section{Costs of Rations and of Calves Produced}

Because of the unusually high percentage of calves dropped, which was due to the practice of substituting cows that were bred for any which failed to breed in time for a spring calf the following year, the cost per cow kept is only slightly less than the cost per calf raised, as Table IX shows. It is considered that the cost of labor, the bull charges, and other expenses are balanced by the manure produced. 


\section{Comparison of Results with Silage and Shock Corn}

\section{TABLE X.-Comparative Value of the Silage Rations and the Shock-corn Ration.*}

\begin{tabular}{|c|c|c|c|c|}
\hline Items Considered & 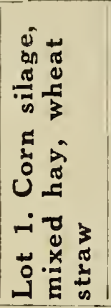 & 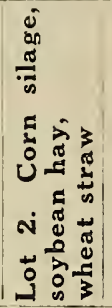 & 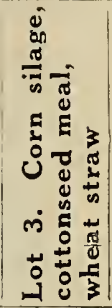 & 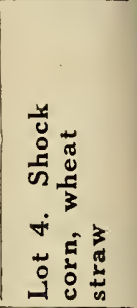 \\
\hline Average yearly gain per cow ...........pounds... & 36 & 49 & 58 & 10 \\
\hline Winter gains and losses per cow....... pounds... & -4 & +47 & +20 & -49 \\
\hline Percentage of calves raised per year..per cent & 97 & 95 & 87 & 90 \\
\hline Average birth weight of calf............ Founds.. & 65.8 & 67.6 & 65.4 & 61.1 \\
\hline 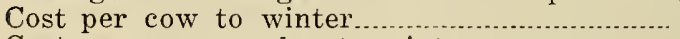 & $\$ 19.69$ & $|\$ 19.32|$ & $\$ 17.88 \mid$ & $\$ 27.50$ \\
\hline Cost per cow per day to winter & .15 & .14 & .14 & $.221 / 2$ \\
\hline Total cost of feed per cow for one year & 33.69 & 33.10 & 31.87 & 42.14 \\
\hline Daily cost of feed per cow for one year...... & .09 & .09 & .09 & $.111 / 2$ \\
\hline 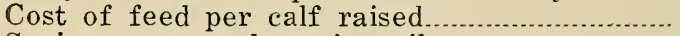 & 34.39 & 34.38 & 36.54 & 46.82 \\
\hline Saving per cow by using silage... & 8.45 & 9.04 & 10.27 & \\
\hline Saving per calf raised.................... & 12.43 & 12.43 & 10.28 & \\
\hline
\end{tabular}

*The winter gains and costs on cows are based on four years' work, the percentage of calves on three years, and the annual gain on two years for Lots 1 and 3 , and one year for Lots 2 and 4 .

\section{Summary of Costs}

Corn silage and wheat straw with either mixed hay, soybean hay, or cottonseed meal is a much cheaper ration than shock corn, mixed hay, and wheat straw for wintering grade beef cows.

As the cows fed on the mixed hay and soybean ration produced a larger calf crop than those fed the cottonseed meal, the average cost per head of raising their calves was practically six per cent less.

As sources of protein, mixed hay, and soybean hay, where they are grown successfully, have additional advantages in that they can be raised on the farm, while cottonseed meal must be purchased, which involves uncertainty as to the availability and the price. 




\section{HECKMAN}

BINDERY INC.

\section{JUNE 99}

N. MANCHESTER

Bound - Io-Please N. MANCHA 46962
INDIANA 
